Wening Ila Idzatilangi ${ }^{1}$, Charistoper Romeo Pasau ${ }^{2}$

Hasanuddin University

Perintis Kemerdekaan Street Km 10, Makassar, South Sulawesi, 90245.

weningilaidzatilangi@gmail.com ; romeo.pasau@gmail.com

\title{
ECONOMIC VALUATION OF MANGROVE FOREST IN TONGAS DISTRICT, PROBOLINGGO REGENCY, EAST JAVA
}

\begin{abstract}
It is a literature review study and was undertaken from 1 December to 15 December 2021. This research aims to identifying the economic value of mangrove forest in Tongas District, Problonggo Regency, East Java. The object being researched was the mangrove forest in Tongas District. The study conducted by objectifying mangrove wood as furniture and other materials, while the mangrove ecosystem is a place to maintain the hydrological cycle and quality, as well as a tourist attraction. The economic valuation will be given from the prices in the marketplaces including the online one. The result of this research showed that the yearly benefits of the ecosystem of mangrove area at Tongas District can be grouped into: (1) direct benefit of IDR 6.638.421; (2) indirect benefits of IDR 3.651.710.094.700; and (3) optional benefits of IDR 325.000. With the total value is IDR. 3.651.717.058.121 per year. With indirect values occupy the highest. So, it can be said, if the role of Mangrove forests as environmental providers is very high. It indicates if there is high need to protect the forest.
\end{abstract}

\section{Introduction}

Mangrove forests have a big role, in terms of supporting the economy of coastal communities around the world (Alongi, 2009). This can be interpreted, if the mangrove forest is able to provide direct economic value to the community. Judging from the ability of mangrove forests in terms of indirect economic value, of course mangrove forests provide many things. Starting from carbon storage, habitat for aquatic animals, and preventing erosion. Mangrove forests have high productivity in sequestering carbon. In this ecosystem, a lot of carbon is stored in the soil and dead roots (Alongi, 2012). However, in the last few decades, the existence of mangroves has been degraded (Alongi, 2015). So, giving value to the mangrove forest is an important thing to do. So that in the future, all actions on mangroves can be considered properly from an economic point of view.

\section{Research Methodology}

On this occasion, the author tries to give an assessment of the mangrove forest in Tongas District. In this case, the author bases the statement based on the variety of libraries found. Reviewing the Probolinggo District Medium-Term Development Plan 2013-2018, it was explained that in Tongas District, a community micro-industry was launched in the form of furniture and fisheries. Here we will give an assessment by objectifying mangrove wood as furniture and other materials, while the mangrove ecosystem is a place to maintain the hydrological cycle and quality, as well as a tourist attraction. The economic valuation will be given from the prices in the marketplaces including the 
online one. This is a literature review study and was undertakenfrom 1 December to 15 December 2021.

\section{Results and Discussion}

There are 7 types of mangrove species there, namely: Avicennia marina, Bruguiera gymnorrhiza, Exocaria agallocha, Rhizopora agallocha, Sonneratia alba, Xylocarpus mollucensis, and Xylocarpus granatum. There are only three species that can be used for their wood, namely Sonneratia alba (Anoop, Job, and Fasil, 2013) for firewood and boat wood, Xylocarpus mollucensis (Dahdouh-Guebas et al, 2000) for firewood and building wood, and Bruguiera gymnorrhiza for firewood (Islam et al, 2006). However, several literatures show the tendency of people not to monetize mangrove forest products, but to use them for their daily life. Such as wood for making fishing boats, firewood for cooking, and so on. A browser shows that the trend of using Sonneratia alba wood is less attractive, but exports continue to occur every year, with the price of wood per $\mathrm{m}^{3}$ being 73U\$. As for the firewood case, here the author gives the price by adjusting the review of the literature that comes from a review of one of the regions in Southeast Asia, namely "Economic Assessment of Mangrove Forest Uses: The Case of Wunbaike Mangrove Forest Myanmar". Firewood has a price of 24.82 per $\mathrm{m}^{3}$. Here the value of building wood is equated with the value of mahogany (timber substitution of teak), because in its use, this wood is not traded. The price of mahogany, according to the wood supplier's browser per cubic, is IDR. $4,500,000$.

\begin{tabular}{llc}
\hline \multicolumn{1}{c}{ Spesies } & \multicolumn{1}{c}{ Uses } & Economic Value (IDR/ $\mathbf{m}^{\mathbf{3}}$ ) \\
\hline Bruguiera gymnorrhiza & Firewood & 359.890 \\
\hline Sonneratia alba & Firewood and Boat Wood & 1.418 .390 \\
\hline Xylocarpus mollucensis & Firewood and Building Wood & 4.859 .890 \\
\hline \multicolumn{2}{r}{ Total } & $\mathbf{6 . 6 3 8 . 1 7 0}$
\end{tabular}

Meanwhile, four other types of mangroves namely Avicennia marina, Exocaria agallocha, Rhizopora apiculate, and Xylocarpus granatum have medicinal functions (Eldohaji et al, 2020; Satyavani et al, 2015; and Bandaranayake, 1998). These four species have various properties, but here the author chooses the most popular used. The price of each product is obtained from the average price of the Tokopedia online store.

\begin{tabular}{llc}
\hline \multicolumn{1}{c}{ Spesies } & \multicolumn{1}{c}{ Uses } & Economic Value (IDR/tablet) \\
\hline Avicennia marina & Smallpox medicine & 55.000 \\
\hline Exocaria agallocha & Antidiabetic medicine & 52.000 \\
\hline Rhizopora apiculata & Flu medicine & 92.000 \\
\hline Xylocarpus granatum & Antidiabetic medicine & 52.000 \\
& & $\mathbf{2 5 1 . 0 0 0}$
\end{tabular}

Assuming one production cycle, Mangrove Forest provides one cubic of wood for each species and 1 medicinal tablet containing 12 grains. The total direct value of the Mangrove Forest in Tongas District is 6,638,170+251,000=IDR. 6,638,421. 
Next, we will examine the indirect economic value of these forests, which include Protection from Seawater Abrasion and Intrusion as well as carbon sequestration.

The value of abrasion protection is obtained from the price issued by the government to build a coastal protection construction, where the structure serves to reduce wave energy in coastal locations (Directorate General of Marine Spatial Management, 2020). While the price of intrusion is obtained from the price of water protection. Seawater intrusion is a phenomenon of decreasing groundwater quality because saltwater also mixes or contaminates (Ashriyanti, 2011). So that here the raw water price in Tongas District is calculated, which means that if seawater intrusion occurs, it will lose in nominal terms equal to the multiplication of the area with the price of raw water. The total area of Tongas District is $77.95 \mathrm{~km}^{2}$ (Central Bureau of Statistics Proboliggo, 2020). While the price of raw water is IDR. 2,325 per cubic meter (Arifin, 2020). Here the valuation is assumed that every square meter of land stores groundwater with an economic cycle of one year.

\begin{tabular}{|c|c|c|}
\hline Types of Disturbance & Price (Rp) & Sources \\
\hline Sea Water Intrusion & 217.123 .375 & PDAM Probolinggo, 2020 \\
\hline Abrasion & 3.651 .166 .000 .000 & Widhianto et al, 2014 \\
\hline Total & 3.651.383.480.500 & \\
\hline
\end{tabular}

Based on Article 13 Paragraph 19 of the Income Tax Law of Indonesia, the price of carbon per kilogram is Rp. 30. Research on carbon accounting has been carried out by Afifudin in 2019 and the results show that the Mangrove Forest in Tongas District, Probolinggo Regency has a carbon storage of 120.7 tons/ha as of 2020. (Note: Mangrove Forest area of Tongas District is $90.2 \mathrm{Ha}$ )

\begin{tabular}{ccc}
\hline Carbon (Ton/Ha) & Price (IDR/Kg) & Total \\
\hline 120,7 & 30 & 326.614 .200
\end{tabular}

Reviewing the existing literature, the local community does not open a mangrove tourism business, but here there is still a value of choice. The value of the choice is obtained from the total cost that is expected to be incurred for the author to be able to visit the book and return home.

\begin{tabular}{|c|c|c|}
\hline Types of Expense & Price (IDR) & Sources \\
\hline Round-Tip Train Ticket & 270.000 & Tiket.com \\
\hline $\begin{array}{l}\text { Transport Price from the Railway } \\
\text { Station to the Mangrove Forest }\end{array}$ & 15.000 & Gojek \\
\hline Consumption Price & 40.000 & Gojek \\
\hline Total & 325.000 & \\
\hline
\end{tabular}

The value of the existence of the forest can be obtained through interviews with local communities about the importance of mangroves. But here it is omitted. Heritage value is obtained if there is a cultural or historical heritage in it, but after searching the library, this is not found. 
So that the total economic valuation is obtained as follows:

\begin{tabular}{|c|c|}
\hline Information & Price (IDR) \\
\hline Direct Value & 6.638 .421 \\
\hline Indirect Value & 3.651 .710 .094 .700 \\
\hline Option Value & 325.000 \\
\hline Total & 3.651.717.058.121 \\
\hline
\end{tabular}

\section{Conclusion}

It can be concluded if the mangrove forest gives direct, indirect, and option values. The total value of the mangrove forest in Tongas District, Probolinggo Regency is IDR. 3,651,717,058,121. With indirect values occupy the highest. So, it can be said, if the role of Mangrove forests as environmental providers is very high. It indicates if there is high need to protect the forest.

Wening Ila Idzatilangi and Charistoper Romeo Pasau Hasanuddin University

\section{References}

Afifudin. M. J. (2019). Analisa Vegetasi Hutan Mangrove dan Serapan $\mathrm{CO}_{2}$ di Kecamatan Tongas Kabupaten Probolinggo Jawa Timur. Undergraduate Thesis. Universitas Islam Negeri Sunan Ampel Surabaya.

Anoop. E. V., Job. J. N., and Fasil. M. M., (2013). Ecoanatomical Characteristics of The Wood of Certain Selected Mangrove Species of Kerala. Zool. Surv. Indias Mangroves in India: Biodiversity, Protection, and Enviromental Services. 435-445.

Alongi. M. D. (2009). The Energetic of Mangrove Forests. Springer Science and Business Media.

Alongi. M. D., (2012). Carbon Sequestration in Mangrove Forest. Journal of Carbon Management. $3(3), 313-322$.

Alongi. M. D., (2015). The Impact of Climate Change on Mangrove Forests. Current Climate Change Reports. 1 (1), 30-39.

Arifin. J. (2020). Penyebab Lonjakan Tagihan PDAM Problonggo: Meteran Dihitung Rerata. Jawa Pos.

Ashriyanti, H. (2011). Kajian Kerentanan pada Wilayah Terintrusi Air Laut di DKI Jakarta. Graduate Thesis. Universitas Indonesia, Depok.

Central Bureau of Statistics Probolinggo. (2020). District Area in Probolinggo Regency.

Bandaranayake. W. M. (1998). Traditional and Medicinal Uses of Mangroves. Mangroves and Salt Marshes. 2 (3), 133-148. 
Dahdouh-Guebas. F., Mathenge. C., Kairo J. G., dan Koedam. N. (2000). Utilization of Mangrove Wood Products Around Mida Creek (Kenya) Amongst Subsistence and Commercial Users. Economy Botany. 54 (5), 513-527.

Indonesia's Directorate General of Marine Spatial Security. 2020. Coast Guard Structures to Overcome Abrasion in PPI Salibabu, SKPT Talaud.

Eldohaji. L. M., Hamoda. A. M., Hamdy. R., and Soliman. S. S. M., (2020). Avicennia Marina a Natural Reservoir of Phytopharmaceuticals: Curative Power and Platform of Medicines. Journal of Ethnopharmacology. 11 (3), 179.

Gojek. Digital Technology Payment Company. Accessed on 02 December 2021.

Islam. M. S., Lian. C. L., Kameyama. N., Wu. B., and Hogetsu. T., (2006). Development and Characterization of Ten New Microsatellite Markers in a Mangrove Tree Species Bruguiera gymnorrhiza (L.). Molecular Ecology Notes. 6 (1), 30-32.

Prot4u. Wood record Display: Sonneratia alba. www.prot4u.org. Accessed on 02 December 2021.

Probolinggo District Medium-Term Development Plan 2013-2018.

San. C. C. (2016). Economic Assesment of Mangrove Forest Uses; The Case of Wunbaike Mangrove Forest in Rakhine State, Myanmar. Kassel University Press. Hal 93.

Satyavani. K., Gurudeeban. S., Manigandan., Rajamanickam. E., and Ramanathan. T., (2015). Chemical Compositions of Medicinal Mangrove Species Acanthus ilicifolius, Exocarcia agallocha, Rhizophora apiculata, and Rhizophora mucronata. Current Research in Chemistry. 7 (1), 1-8.

Supplier Kayu. Online Wood Store. www.supplierkayu.com. Accessed on 02 December 2021.

Tiket.com. Online Trip Ticket Store. Accessed on 01 December 2021.

Tokopedia. Convenience Online Store. Accessed on 01 December 2021.

Widhianto. S. L., Kharisma. D., Suharyanto., and Hardiyati. S., (2014). Kajian Struktur Pengaman Pantai Sigandu Batang. Jurnal Karya Teknik Sipil. 3 (4), 1207-1221.

Wijaya. D., Suryono., and Soenardjo. N., (2019). Ekologi Mangrove di Pesisir Kecamatan Tongas dan Sumberasih Kabupaten Probolinggo Jawa Timur. Journal of Marine Research. 8 (2), 218-222. 